\title{
ABO and Rh Blood Groups and Risk of Myelomeningocele
}

\author{
Semra ISIK ${ }^{1}$, Serdar CEVIK², Ali Haydar TURHAN ${ }^{3}$, Arzu BAYGUL ${ }^{4}$, Hakan HANIMOGLU ${ }^{5}$ \\ ${ }^{1}$ Baskent University Istanbul Health Research and Application Center, Department of Neurosurgery, Istanbul, Turkey \\ ${ }^{2}$ Sisli Memorial Hospital, Department of Neurosurgery, Istanbul, Turkey \\ ${ }^{3}$ Baskent University Istanbul Health Research and Application Center, Department of Neonatology, Istanbul, Turkey \\ ${ }^{4}$ Koc University, School of Medicine, Department of Biostatistics, Istanbul, Turkey \\ ${ }^{5}$ Biruni University School of Medicine, Department of Neurosurgery, Istanbul, Turkey
}

Corresponding author: Semra ISIK drsemraisik@gmail.com

\section{ABSTRACT}

AIM: To investigate the relationship between the distribution of $A B O$ or Rhesus $(\mathrm{Rh})$ blood group antigens and the incidence of myelomeningocele.

MATERIAL and METHODS: A retrospective data was reviewed for all myelomeningocele patients operated at a tertiary academic hospital between years 2014 and 2019. Age, sex, delivery method, physical and neurological examination findings, and radiological findings alongside with blood type of each patient were recorded. The data of blood group distribution among the study patients was compared to the data of healthy individuals in the same region.

RESULTS: Patients with group B and AB showed a higher chance of developing myelomeningocele. Rh-positive blood group was associated with high incidence of myelomeningocele (93.5\%), whereas Rh-negative blood group showed least association (6.5\%). Rh-positive blood group was also found to be more frequent in patients with myelomeningocele with hydrocephalus and Chiari malformation.

CONCLUSION: The findings of this study show that $\mathrm{ABO}$ and $\mathrm{Rh}$ blood groups have an effect on the development of myelomeningocele under the influence of environmental or genetic factors.

KEYWORDS: ABO blood groups, Myelomeningocele, Neural tube defects, Rh blood groups

ABBREVIATIONS: GBM: Glioblastoma Multiforme, Me-THF: Methyltetrahydrofolate, MMC: Myelomeningocele, MTHFR: Methylenetetrahydrofolate reductase gene, RBCs: Red Blood Cells, Rh: Rhesus, RR: Relative ratio, SARDH: Sarcosine dehydrogenase gene

\section{INTRODUCTION}

$\mathrm{M}$ yelomeningocele (MMC), also known as open spina bifida, is the most common neural tube defect but its multifactorial etiology is still poorly understood. Both environmental and genetic factors contribute to MMC development $(5,7,8,18)$ so that the incidence of MMC varies in different parts of the world and among ethnic groups (45). Disorders in folate-dependent single carbon metabolism may affect cellular reactions crucial for appropriate neural tube closure, such as cell proliferation, survival, differentiation, and migration $(3,25)$. Genetic alterations in the $9 q 34.2$ region [Sarcosine dehydrogenase gene (SARDH)] and the 1p36 regions [Methylenetetrahydrofolate reductase gene (MTHFR)], which have roles in folate metabolism, have been reported to be risk factors for the development of neural tube defects $(4,10,36)$.

\begin{tabular}{llll}
\hline Semra ISIK & (1) $: 0000-0002-6929-7135$ & Arzu BAYGUL & (1) : 0000-0003-0392-6709 \\
Serdar CEVIK & (1) : $0000-0002-2733-4233$ & Hakan HANIMOGLU & (1) $: 0000-0002-8830-9525$ \\
Ali Haydar TURHAN (i) $: 0000-0003-4018-1179$ & &
\end{tabular}


ABO blood group and Rhesus (Rh) D antigens are polymorphic, antigenic, genetic substances found mostly on the surface of red blood cells (RBCs) but also on some other cells and tissues. Hereditary polymorphic features transferred between individuals and communities can be found in blood group antigens (16). $\mathrm{ABO}$ and $\mathrm{Rh}$ blood groups are seen at the entire human population, however their frequency and distribution are different among nations and races $(6,9)$. The genetic localization of ABO blood group antigens is on the 9q34.2 region, whereas that for the $\mathrm{Rh}$ blood group antigen is on the 1 p36 region $(2,32)$.

After being defined at the beginning of the $20^{\text {th }}$ century, several studies have been performed to investigate the relationship between $\mathrm{ABO}$ and $\mathrm{Rh}$ blood groups and various metabolic and malignant diseases. Early publications on this subject claimed that cancer, peptic ulcer, and thrombotic diseases were associated with ABO blood groups $(19,34,36)$. Furthermore, recent review and meta-analysis studies have confirmed the connection between the distribution of $\mathrm{ABO}$ blood group antigens and the risk of developing specific types of cancer $(13,20-22,27,47)$. Relations between blood groups and type 2 diabetes mellitus (24), obesity (17), stomach and duodenal ulcer $(38,40)$, Hepatitis-B (37), vascular diseases (46), and abdominal aortic aneurism (11) have also been reported in previous studies.

Since $A B O$ and $R h$ antigens and some important enzymes in the folate pathways share gene loci, we hypothesized that there is a relationship between RBC surface antigens and MMC development. Thus, in this study, we investigated the relationship between the distribution of $\mathrm{ABO}$ or $\mathrm{Rh}$ blood group antigens and the incidence of MMC in Turkish people.

\section{MATERIAL and METHODS}

This study was approved by Baskent University Institutional Review Board (Project no: 94603339-604.01.02/44399) and supported by Baskent University Research Fund. We retrospectively reviewed all cases of MMC referred to and operated upon at our hospital between July 2014 and November 2019. Gestational age; maternal age; sex; delivery method (vaginal vs cesarean section); physical, neurological, and radiological examination findings; and blood group were retrieved from the hospital data system and recorded for each patient. The data of blood group distribution among our patients was compared to that collected from 6041 healthy individuals in 2015 from the same region (35).

\section{Statistical Analysis}

The Kolmogorov-Smirnov test was used to determine the normality of the distribution of the continuous variables. Continuous variables with normal distribution were expressed as mean ( \pm standard deviation). Variables with skewed distribution were expressed as median (minimum-maximum), and categorical variables were expressed as percentage (\%). Chi-square test was performed for the comparison of two proportions (from independent samples), expressed as a percentage. Statistical analysis was with MedCalc Statistical Software version 18.11.3 (MedCalc Software bvba,
Ostend, Belgium; https://www.medcalc.org; 2019) and SPSS version 20.0 for Windows. A P value of $<0.05$ was defined as statistically significant.

\section{RESULTS}

A total of 77 patients were diagnosed with $\mathrm{MMC}$ and operated upon (Table I). The distribution of blood groups in these patients was as follows: A: 31 (40.2\%), B: 15 (19.5\%), O: 23 (29.9\%), AB: 8 (10.4\%); $\mathrm{Rh}(+): 72$ (93.5\%), $\mathrm{Rh}(-)$ : 5 (6.5\%) (Table I).

Table I: Demographic Features of Myelomeningocele Patients

\begin{tabular}{|c|c|}
\hline Characteristic & Value \\
\hline Maternal Age (years) & $27.8 \pm 5.97$ \\
\hline Gender & n (\%) \\
\hline Male & $36(47)$ \\
\hline Female & $41(53)$ \\
\hline Method of Delivery & n (\%) \\
\hline Vaginal & $15(19)$ \\
\hline Caesarian-section & $62(81)$ \\
\hline Lesion Level & n (\%) \\
\hline Cervical & $2(2.6)$ \\
\hline Thoracic & $5(6.5)$ \\
\hline Thoracolumbar & $30(39.0)$ \\
\hline Lumbar & $34(44.1)$ \\
\hline Sacral & $6(7.8)$ \\
\hline Hydrocephalus & n (\%) \\
\hline$(+)$ & $58(75)$ \\
\hline$(-)$ & $19(25)$ \\
\hline Chiari Malformation & n (\%) \\
\hline$(+)$ & $54(70.0)$ \\
\hline$(-)$ & $23(30.0)$ \\
\hline Kyphosis & n (\%) \\
\hline$(+)$ & $28(36)$ \\
\hline$(-)$ & $49(64)$ \\
\hline Syringomyelia & n (\%) \\
\hline$(+)$ & $30(39)$ \\
\hline$(-)$ & $47(61)$ \\
\hline Blood groups & n (\%) \\
\hline A & $31(40.2)$ \\
\hline $\mathrm{B}$ & $15(19.5)$ \\
\hline 0 & $23(29.9)$ \\
\hline$A B$ & $8(10.4)$ \\
\hline $\mathrm{Rh}(+)$ & $72(93.5)$ \\
\hline $\operatorname{Rh}(-)$ & $5(6.5)$ \\
\hline
\end{tabular}

n: number of patients, \%: percentage, Rh: Rhesus, y: years. 
When comparing patients with MMC with healthy blood donor controls, the presence of $B$ and $A B$ blood groups were found $21 \%$ and $26 \%$ higher at MMC patients. However these results were not statistically significant in association with a risk of developing MMC. Relative risk (RR) ratio of patients with $B$ and $A B$ blood groups compared to $O$ blood group were 1.33 and 1.34 , respectively. This suggests that individuals with group $B$ and $A B$ have a higher than expected chance of developing MMC. "Rh-positive" blood type was associated with high incidence of MMC (93.5\%), whereas "Rh-negative" blood group showed least association with MMC (6.5\%). Comparison of healthy controls with the MMC group revealed that $\mathrm{Rh}$-positive patients were at higher risk of MMC development $(p=0.42)$. Patients with Rh-positive blood group showed significantly higher probability of developing MMC when compared with $\mathrm{Rh}$-negative patients $(\mathrm{RR}=2.33)$

Subgroup analysis according to concomitant pathologies (such as hydrocephalus, kyphosis, syringomyelia, and Chiari malformation) revealed that $\mathrm{Rh}$-positive blood group was more frequent in patients with MMC with hydrocephalus and Chiari malformation. $\mathrm{B}$ blood group was found more often in patients with $\mathrm{MMC}$ with kyphosis or syringomyelia than in healthy individuals. $A B$ blood group was observed less frequently in patients with $M M C$ with kyphosis, whereas $O$ blood group was seen less in patients with MMC with syringomyelia than in the normal population (Table II).

\section{DISCUSSION}

In this study, we evaluated the relationship between the most common blood group antigens and myelomeningocele. To our knowledge, this is the first study to evaluate $A B O$ and $R h$ blood groups as risk factors for the development of MMC. Among MMC cases and controls from large cohort studies in same regions, we observed a significantly elevated risk for MMC among those with B blood group compared with those with non-B blood groups. The highest risk was found in patients with $B$ blood group, followed by an intermediate risk in patients with $A B$ blood group. In addition, Rh positivity was found to be associated with MMC development.

Neural tube defects are among the multi-factorial disorders on the basis of genetic predisposition. One of the most environmental important risk factors for MMC is low maternal folate intake. Therefore, the preconceptional folic acid usage has been reported in the literature as one of the preventative measures used to reduce the risk of MMC development. As a result, MMC development and recurrence were reduced by $50 \%$ to $85 \%(14,26)$. However, genetic variations that cause inadequate functioning of endogenous folate metabolism, such as the $667 \mathrm{C}>\mathrm{T}$ polymorphism in the MTHFR gene, are associated with increased risk of MMC $(4,14)$.

Folate metabolites play asignificantrole as cofactors of many different enzymes involved in processes such as purine and pyrimidine synthesis, DNA and protein methylation (14). Deficiencies in folate-dependent one-carbon metabolism, which is crucial for methylation reactions and nucleic acid synthesis, play an important role in MMC development (4).

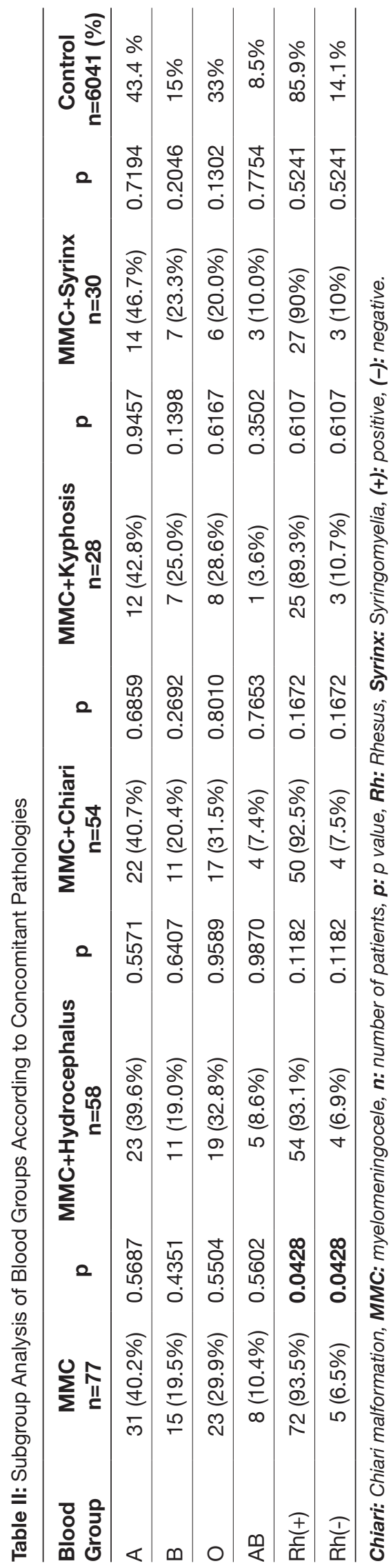


Disorders in this metabolism may affect cellular responses necessary for proper neural tube formation, such as cell proliferation, survival, differentiation, and migration $(3,25)$. It is known that variations of MTHFR gene on chromosome 1 p36 and SARDH gene on chromosome 9q34 in endogenous folate metabolism significantly increase the risk of MMC development $(14,28,29,31,42,44)$. Methyltetrahydrofolate (Me-THF), the product of MTHFR, is the predominant circulating form of folate. However, folate forms like 5,10-methylenetetrahydrofolate, a substrate of MTHFR, are mainly inside the cell and do not circulate. Polymorphism in the MTHFR gene disrupts folate metabolism and causes a decrease in plasma folate levels (43). SARDH-encoded sarcosine dehydrogenase is a catalyzer at the oxidative demethylation of sarcosine glycine (a key intermediate product in folate-dependent carbon metabolism) to promote folatemediated transfer of monocarbon units required for DNA synthesis and repair (15,31). However, significantly increased levels of homocysteine have been found at pregnancies affected by MMC, making SARDH a more valuable genetic factor for MMCs $(31,39)$. These two molecules are very important for embryonic development. In particular, the amino acid polymorphism of SARDH (rs2073817) significantly increases the risk of MMC (31). These two enzymes, which are important for the continuity of folate metabolism, are located on the same chromosomes as ABO antigens (chromosome 9q34) and Rh antigen (1p36).

Previous studies have found associations of $\mathrm{ABO}$ blood groups with pathologies such as Alzheimer's disease $(23,33)$, neurodegenerative diseases (12), neurological diseases, and neoplastic lesions of the central nervous system (20) such as glioblastoma multiforme (GBM) $(1,41)$ or astrocytoma $(30)$. In their study of patients with GBM, Allouh et al. reported a 2.1 times increased risk in patients with $A$ blood group compared with those with O blood group (1). In this study, we performed a retrospective analysis of patients treated for $\mathrm{MMC}$ to investigate the effect of $\mathrm{ABO}$ and $\mathrm{Rh}$ blood groups on MMC development. In our study compared with patients with $O$ blood group, those with $\mathrm{AB}$, or $\mathrm{B}$ blood group were more likely to develop MMC (RR: 1.331 .34 , respectively). Due to the close similarity between genetic locations of important enzymes in folate metabolism and $\mathrm{ABO}$ and $\mathrm{Rh}$ antigens, allele variants in $\mathrm{ABO}$ and Rh genes on chromosomes 9q34 and 1p36 may be an important site for MMC hereditary susceptibility.

\section{CONCLUSION}

In conclusion, we have found differences in the distribution pattern of $\mathrm{ABO}$ blood groups in patients with MMC compared with the general healthy population. Individuals with $\mathrm{Rh}$ antigen had a high risk of developing MMC. Based on the findings of this study, we suggest that $\mathrm{ABO}$ and $\mathrm{Rh}$ blood groups have an impact on the development of MMC under the influence of environmental or genetic factors.

\section{REFERENCES}

1. Allouh MZ, Al Barbarawi MM, Hiasat MY, Al-Qaralleh MA, Ababneh El: Glioblastoma and ABO blood groups: further evidence of an association between the distribution of blood group antigens and brain tumours. Blood Transfus 15(6):543547,2017

2. Avent ND, Reid ME: The Rh blood group system: A review. Blood 95(2):375-387, 2000

3. Beaudin AE, Stover PJ: Insights into metabolic mechanisms underlying folate-responsive neural tube defects: A minireview. Birth Defects Res A Clin Mol Teratol 85:274-284, 2009

4. Blom HJ, Shaw GM, den Heijer M, Finnell RH: Neural tube defects and folate: Case far from closed. Nat Rev Neurosci 7: 724-731, 2006

5. Copp AJ, Greene ND: Neural tube defects: Prevention by folic acid and other vitamins. Indian J Pediatr 67:915-921, 2000

6. Cildag S, Kara Y, Senturk T: ABO blood groups and rheumatic diseases. Eur J Rheumatol 4:250-253, 2017

7. De Marco P, Merello E, Mascelli S, Capra V: Current perspectives on the genetic causes of neural tube defects. Neurogenetics 7:201-221, 2006

8. Detrait ER, George TM, Etchevers HC, Gilbert JR, Vekemans M, Speer MC: Human neural tube defects: Developmental biology, epidemiology, and genetics. Neurotox Teratol 27:515524, 2005

9. Donbak L, Rencuzogullari E, Topaktas M, Kayrın L: Detection of some blood group (ABO, RH-D) and serum protein (HP, a1AT, TF) polymor-phisms in Antakya Province, Turkey. T Klin J Med Res 20:109-113, 2002

10. Enaw JO, Zhu H, Yang W, Lu W, Shaw GM, Lammer EJ, Finnell $\mathrm{RH}$ : CHKA and PCYT1A gene polymorphisms, choline intake and spina bifida risk in a California population. BMC Med 4: 36, 2006

11. Fatic N, Lukac H, Radojevic N, Simanic I, Banzic I, Pajovic BO: Blood group as an indicator for abdominal aortic aneurysm. Eur Rev Med Pharmacol Sci 19:2997-3000, 2015

12. Franchini M, Liumbruno GM: $A B O$ blood group and neurodegenerative disorders: More than a casual association. Blood Transfus 14(2):158-159, 2016

13. Franchini M, Liumbruno GM, Lippi G: The prognostic value of ABO blood group in cancer patients. Blood Transfus 6:1-7, 2015

14. Franke B, Vermeulen SH, Steegers-Theunissen RP, Coenen MJ, Schijvenaars MM, Scheffer $H$, den Heijer M, Blom HJ: An association study of 45 folate-related genes in spina bifida: Involvement of cubilin (CUBN) and tRNA aspartic acid methyltransferase 1 (TRDMT1). Birth Defects Res A Clin Mol Teratol 85(3):216-226, 2009

15. Green T, Chen X, Ryan S, Asch AS, Ruiz-Echevarría MJ: TMEFF2 and SARDH cooperate to modulate one-carbon metabolism and invasion of prostate cancer cells. Prostate 73:1561-1575, 2013

16. Hakyemez IN, Durdu B, Bolukcu S, Aslan T: Evaluation of the relationship between $\mathrm{ABO} / \mathrm{Rh}$ blood groups and severity of liver fibrosis in patients with chronic hepatitis B. Viral Hepat $J$ 22:23-27, 2016 
17. Jawed S, Atta K, Tariq S, Amir F: How good is the obesity associated with blood groups in a cohort of female university going students? Pak J Med Sci 34(2):452-456, 2018

18. Jensen LE, Barbaux S, Hoess K, Fraterman S, Whitehead AS, Mitchell LE: The human T locus and spina bifida risk. Hum Gene 115:475-482, 2004

19. Jick $H$, Slone $D$, Westerholm B, Inman WH, Vessey MP, Shapiro S, Lewis GP, Worcester J: Venous thromboembolic disease and $\mathrm{ABO}$ blood type. A cooperative study. Lancet 1 : 539-542, 1969

20. Kumarguru BN, Pallavi P, Sunila, Manjunath GV, Vasan TS, Rajalakshmi BR: Histopathological study of central nervous system lesions: emphasizing association of neoplasms with ABO blood groups. J Clin Diagn Res 11(4):EC15-EC20, 2017

21. Liumbruno GM, Franchini M: Beyond immunohaematology: The role of the $\mathrm{ABO}$ blood group in human diseases. Blood Transfus 11:491-499, 2013

22. Liumbruno GM, Franchini M: Hemostasis, cancer and $A B O$ blood group: The most recent evidence of association. J Thromb Thrombolysis 38:160-166, 2014

23. Mehne P, Grunwald P, Gerner-Beuerle E: A serogenetic approach to the study of Alzheimer's disease (author's transl). Aktuelle Gerontol 6(6):259-266, 1976

24. Meo SA, Rouq FA, Suraya F, Zaidi SZ: Association of ABO and Rh blood groups with type 2 diabetes mellitus. Eur Rev Med Pharmacol Sci 20:237-242, 2016

25. Molloy AM, Brody LC, Mills JL, Scott JM, Kirke PN: The search for genetic polymorphisms in the homocysteine/folate pathway that contribute to the etiology of human neural tube defects. Birth Defects Res A Clin Mol Teratol 85:285-294, 2009

26. MRC vitamin study research group: Prevention of neural tube defects: Results of the medical research council vitamin study. Lancet 338:131-137, 1991

27. Oguz A, Unal D, Tasdemir A, Karahan S, Aykas F, Mutlu H, Cihan YB, Kanbay M: Lack of any association between blood groups and lung cancer, independent of histology. Asian Pac J Cancer Prev 14:453-456, 2013

28. Ou CY, Stevenson RF, Brown VK, Schwartz CE, Allen WP, Khoury M, Oakley GP, et al: C677T homozygosity associated with thermolabile 5,10-methylenetetrahydrofolate reductase as a risk factor for neural tube defects. Am J Hum Genet Suppl 57:A223, 1995

29. Pangilinan F, Molloy AM, Mills JL, Troendle JF, ParleMcDermott A, Signore C, O'Leary VB, Chines P, Seay JM, Geiler-Samerotte K, Mitchell A, VanderMeer JE, Krebs KM, Sanchez A, Cornman-Homonoff J, Stone N, Conley M, Kirke PN, Shane B, Scott JM, Brody LC: Evaluation of common genetic variants in 82 candidate genes as risk factors for neural tube defects. BMC Med Genet 13:62, 2012

30. Pearce KM, Yates PO: Blood groups and brain tumours. J Neurol Sci 2:434-441, 1965

31. Piao W, Guo J, Bao Y, Wang F, Zhang T, Huo J, Zhang K: Analysis of polymorphisms of genes associated with folatemediated one-carbon metabolism and neural tube defects in Chinese Han Population. Birth Defects Research (Part A) 106: 232-239, 2016
32. Reid ME, Mohandas N: Red blood cell blood group antigens: Structure and function. Semin Hematol 41(2):93-117, 2004

33. Renvoize EB: ABO and Rhesus blood groups in Alzheimer's disease. Age Ageing 14(1):43-45, 1985

34. Roberts JA: The relationship of the $A B O$ blood groups to cancer. Acta Unio Int Contra Cancrum 10:155-156, 1954

35. Salduz ZiY, Cetin G, Karatoprak C, Ozder A, Bilginc M, Gultepe I, Gul O: ABO and Rh blood group distribution in Istanbul Province (Turkey). Istanbul Med J 16:98-100, 2015

36. Shaw GM, Lammer EJ, Zhu H, Baker MW, Neri E, Finnell RH: Maternal periconceptional vitamin use, genetic variation of infant reduced folate carrier (A80G), and risk of spina bifida. Am J Med Genet 108:1-6, 2002

37. Siransy LK, Nanga ZY, Zaba FS, Tufa NY, Dasse SR: ABO/ Rh blood groups and risk of HIV infection and Hepatitis $B$ among blood donors of Abidjan, Côte D'ivoire. Eur J Microbiol Immunol 18:205-209, 2015

38. Sorensen $\mathrm{KH}$ : Peptic ulcer and the ABO blood group system. Dan Med Bull 4:45-47, 1957

39. Tang KF, Li YL, Wang HY: Quantitative assessment of maternal biomarkers related to one-carbon metabolism and neural tube defects. Sci Rep 5:8510, 2015

40. Tanikawa C, Urabe Y, Matsuo K, Kubo M, Takahashi A, Ito H, Tajima K, Kamatani N, Nakamura Y, Matsuda K: A genomewide association study identifies two susceptibility loci for duodenal ulcer in the Japanese population. Nat Genet 44:430434, 2012

41. Turowski K, Czochra M: AB0 blood groups in glioblastoma multiforme. Neurol Neurochir Pol 13:173-176, 1979

42. van der Linden IJ, Afman LA, Heil SG, Blom HJ: Genetic variation in genes of folate metabolism and neural-tube defect risk. Proc Nutr Soc 65:204-215, 2006

43. van der Put NM, Gabreëls F, Stevens EM, Smeitink JA, Trijbels FJ, Eskes TK, van den Heuvel LP, Blom HJ: A second common mutation in the methylenetetrahydrofolate reductase gene: An additional risk factor for neural-tube defects? Am J Hum Genet 62(5):1044-1051, 1998

44. Whitehead AS, Gallagher P, Mills JL, Kirke PN, Burke $H$, Molloy AM, Weir DG, et al: A genetic defect in the 5,10-methylenetetrahydrofolate reductase in neural tube defects. Q J Med 88:763-766, 1995

45. Zaganjor I, Sekkarie A, Tsang BL, Williams J, Razzaghi H, Mulinare J, Sniezek JE, Cannon MJ, Rosenthal J: Describing the prevalence of neural tube defects worldwide: A systematic literature review. PLoS One: 11(4):e0151586, 2016

46. ZakaiNai, Judd SE, Alexander K, Mcclure LA, Kissela BM, Howard G, Cushman M: ABO blood type and stroke risk: The reasons for geographic and racial differences in stroke study. J Thromb Haemost 12:564-570, 2014

47. Zhang BL, He N, Huang Y, Song F, Chen KX: ABO blood groups and risk of cancer: A systematic review and metaanalysis. Asian Pac J Cancer Prev 15:4643-4650, 2014 